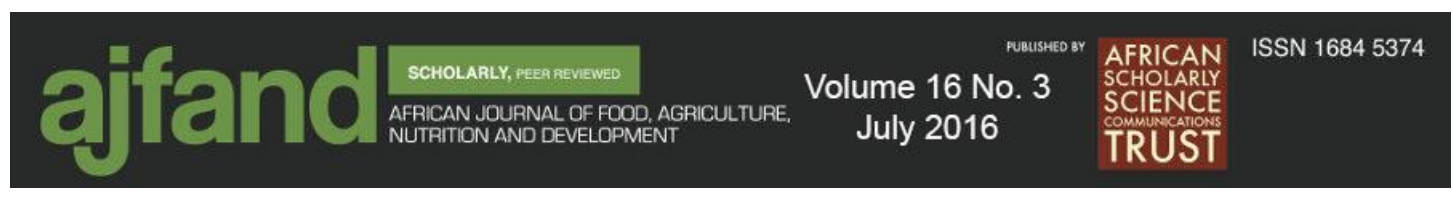

10.18697/ajfand.75.ILRI01

\title{
ASSESSING THE IMPACT OF AFLATOXIN CONSUMPTION \\ ON ANIMAL HEALTH AND PRODUCTIVITY
}

\author{
Atherstone $\mathrm{C}_{1 *}$, Grace $\mathrm{D}_{2}$, Lindahl $\mathrm{JF}_{2,3}$, \\ Kang'ethe EK 4and F Nelsons
}

*Corresponding author email: c.atherstone@,cgiar.org

${ }^{1}$ International Livestock Research Institute, P.O. Box 24384, Kampala, Uganda

${ }^{2}$ International Livestock Research Institute, P.O. Box 30709-00100, Nairobi, Kenya

${ }^{3}$ Swedish University of Agricultural Sciences, P.O. Box 7054, SE-750 07 Uppsala, Sweden

${ }^{4}$ University of Nairobi, P.O. Box 29053-00625, Nairobi, Kenya

${ }^{5}$ International Institute of Tropical Agriculture, P.O. Box 34441, Dar es Salaam,

Tanzania 


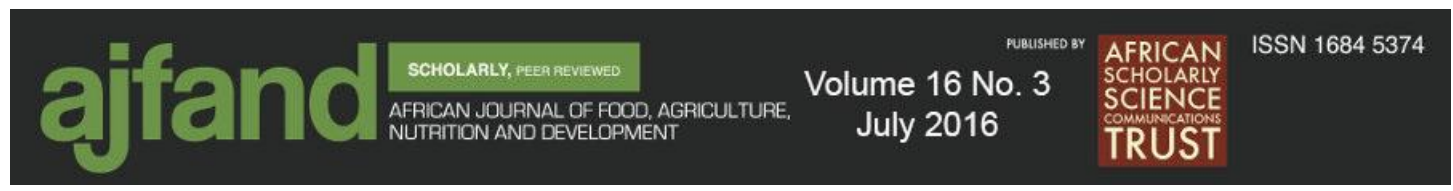

\begin{abstract}
Malnutrition is a major problem in East Africa and animal source foods could provide essential protein and micronutrients to help alleviate this. The livestock sector is rapidly growing and intensifying in response to increased consumer demand for animal source foods. However, the ability of the livestock sector to contribute to improving nutritional security is constrained by a number of factors, including contaminants in animal source foods and feeds. Globally, mycotoxins (especially aflatoxins) are the most important contaminants of livestock feed. Aflatoxins are produced by the fungus Aspergillus flavus and related species, which occur naturally in soils throughout sub-Saharan Africa. They are toxic to humans, fish and many other animals, even in low concentrations. Susceptibility to aflatoxins varies by age, health status, species and other factors. Most research has focused on aflatoxins in maize or groundnuts and their impacts on human health. However, aflatoxins are found in other foods and can also impair livestock productivity, reducing the availability of nutritious foods and the income of smallholder farmers. Aflatoxins are also transferred into animal source foods, which could harm consumers. The objective of this review was to synthesize information on the impact of aflatoxins on livestock health and productivity, with a special focus on reports from East Africa. A systematic literature review identified 2700 abstracts in 23 databases. Of these, 46 articles were relevant to the review objective and available. This review summarises key data on impacts of aflatoxins in animal health and levels of aflatoxins in animal source foods. The studies and surveys suggest that aflatoxins may be a significant risk to livestock productivity and food safety in East Africa. Impacts are likely to worsen as livestock industries intensify in response to the growing demand for animal source foods. Climate change may also aggravate aflatoxin problems. In light of this challenge, this review identifies major research gaps and discuss the way forward.
\end{abstract}

Key words: mycotoxins, livestock, animal source foods, food security, food safety, East Africa, aflatoxins, fish 


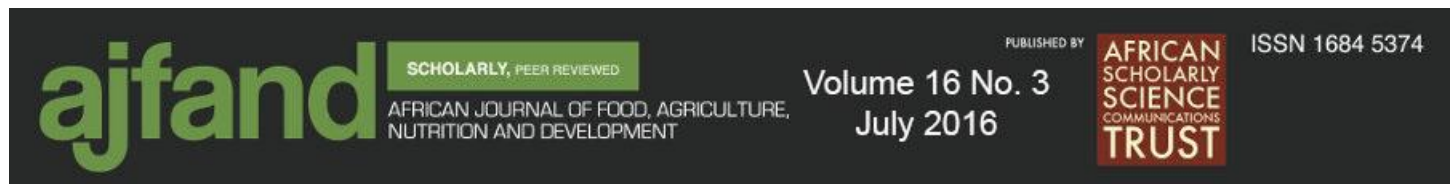

\section{INTRODUCTION}

Malnutrition, including micronutrient deficiencies, is a major problem in East Africa. Animal source foods are essential sources of protein and micronutrients and could contribute to improving nutritional security. Indeed the livestock sector in East Africa is growing rapidly in response to increased demand [1]. Production gains can be obtained most readily by intensifying short cycle species (poultry and pigs) and dairy and egg production. But as these livestock systems intensify, they rely more on nutrient dense feeds (concentrates). Commonly used livestock feeds are based on maize, groundnuts, soybean products, oil cake, fishmeal and brewers' grains, all of which are prone to contamination with aflatoxins [2].

Aflatoxins are produced by the fungi Aspergillus flavus, A. parasiticus and occasionally other Aspergillus species [3]; they are common contaminants of foods and feeds in tropical and sub-tropical regions. At least 20 types of aflatoxin naturally occur, but only four types are commonly found in plant based foods; these are called aflatoxin $\mathrm{B}_{1}, \mathrm{~B}_{2}$, $\mathrm{G}_{1}$ and $\mathrm{G}_{2}$. When animals consume aflatoxins $\mathrm{B}_{1}$ and $\mathrm{B}_{2}$, some is converted in the liver to the metabolites aflatoxin $\mathrm{M}_{1}$ and $\mathrm{M}_{2}$; these are rapidly excreted in milk and urine [4]. Aflatoxins may also be carried over from feed to poultry eggs and some remains in the body as residues in meat and organs [5, 6]. Aflatoxins can also be present in animal source foods as the result of accidental contamination of livestock products with Aspergillus fungi or deliberate introduction during mould fermenting of animal source foods [7].

Aflatoxin consumption causes liver cancer in people and has been associated with stunting and other health problems [8-14]. Consumption of very high levels of aflatoxins by animals also results in severe, sudden onset illness and death. Aflatoxicosis was first identified when more than 100,000 turkeys died in the United Kingdom and feed containing contaminated groundnuts imported from Brazil was implicated [15]. Since then, field outbreaks causing morbidity and mortality have been well documented in turkeys, laying hens, pigs, cattle, rainbow trout and dogs [16]. No exclusively livestock outbreaks have been reported from East Africa; however, in a major Kenyan outbreak, affected households reported the death of their pet dogs, probably due to aflatoxin ingestion [17]. Adverse impacts are more severe where there is co-contamination with other mycotoxins $[2,18]$. Consumption of lower levels of aflatoxins can cause liver damage, gastrointestinal dysfunction, immunosuppression, decreased appetite, decreased reproductive function, decreased growth and decreased production [3].

Toxicity is influenced by environmental factors, exposure level and duration of exposure in tandem with age, health and nutritional status [2]. Foetuses are very susceptible to even low levels of aflatoxins and young and fast-growing animals are more affected than adults; some authors have reported that females are more affected than males [18]. Aflatoxin $\mathrm{B}_{1}\left(\mathrm{AFB}_{1}\right)$ is considered the most toxic and is produced by both $A$. flavus and A. parasiticus. $\mathrm{AFB}_{1}$ is carcinogenic and teratogenic in both humans and animals. To date, $\mathrm{AFB}_{1}$ is the only mycotoxin classified as a Group 1a human carcinogen by the International Agency for Research on Cancer [19]. 


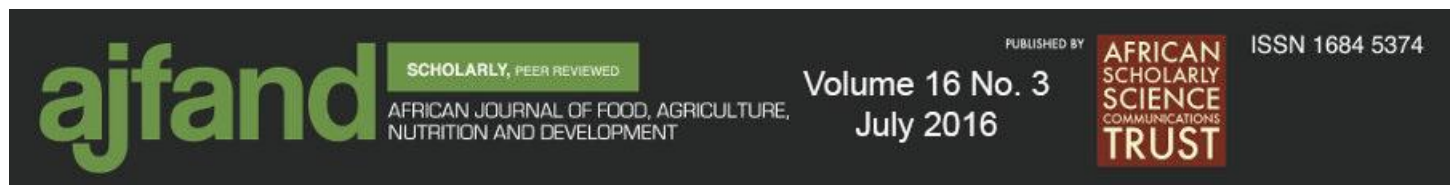

Most aflatoxin research has focused on aflatoxins in grains and their impacts on human health. The objective of this review was to synthesize information on this important but neglected area by conducting a systematic literature review on the impact of aflatoxins on livestock health and productivity, with a special focus on East Africa.

\section{METHODS}

A systematic literature review was undertaken following PRISMA [20] guidelines to capture information on aflatoxin impacts on livestock health and productivity, and the risks associated with aflatoxin contamination of animal feeds and animal source foods (dairy products, meat, eggs, fish, other aquatic foods and honey). Twenty-three (23) databases were searched using a combination of the MESH terms: Africa, sub-Saharan Africa, swine, pigs, poultry, chickens, layers, broilers, dairy, goats, sheep, shoats, cattle, cows, fish, animal feed, animal source foods, livestock, aflatoxin and mycotoxin. Abstracts of identified papers were read, and if relevant to the review objective, full papers were obtained. Information from the papers was captured using a Microsoft Excel template. Data were categorised by natural or experimental exposure and by species, breed and age.

Identified papers used different units for measuring aflatoxin levels. For consistency in this article, units were converted to parts per billion (ppb) which is equivalent to $\mu \mathrm{g} / \mathrm{kg}$; or parts per trillion (ppt), which is equivalent to $\mathrm{ng} / \mathrm{kg}$.

\section{RESULTS}

An initial 2700 papers were identified as part of a broader systematic literature review to capture information on aflatoxin prevalence, risk factors and control options and costs to support risk maps and evidence around costs and controls. After screening for relevance to animal health and productivity, 46 full papers, which were available and had information relevant to the review, were retained for data extraction and inclusion in this report, which emphasizes papers from East Africa.

\section{Livestock sector in East Africa}

The dairy cattle population of the East African Community (EAC) is estimated at 16.4 million, of which 5.5 million are improved breeds. The commercial poultry population is estimated at 8 million in Kenya, 6.5 million in Uganda, 1.7 million in Tanzania and 1.6 million in Rwanda; the sector is less developed in Burundi [21]. The commercial pork sector is estimated at 150,000 pigs in Kenya and is under-developed in other EAC countries. Uganda is experiencing massive expansion of the pork sector [22]. However, this growth is mainly in the smallholder sector, mostly managed by women and children in backyard activities [23].

Kenya produces about 500,000 tonnes of animal feed per year [24] and Tanzania 800,000 tonnes [25]. In Uganda the annual production of compound feeds by the commercial feed millers is estimated at about 80,000 tonnes [26] with around half produced by small-scale mixers [27]. Approximately $70 \%$ of the feeds produced in Kenya are poultry feeds [28] 


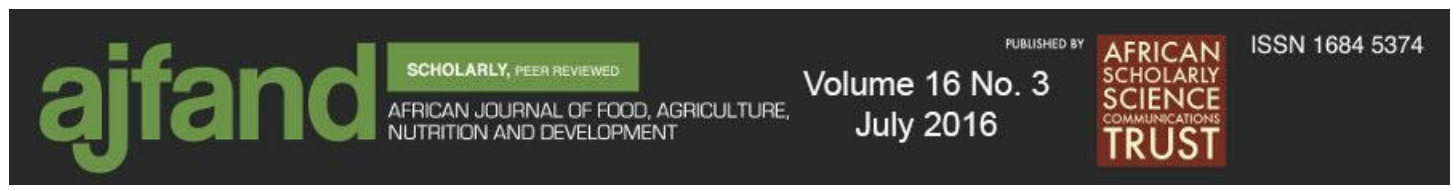

and this may also be the case in other East African countries, as their livestock sectors are broadly similar.

\section{Dairy cattle}

A study from 1982 reported a significant decrease in milk production when dairy cattle $(\mathrm{n}=10)$ were experimentally fed $13,000 \mathrm{ppb}$ un-purified aflatoxin per day for seven days, compared to dairy cattle on an aflatoxin free diet; feeding the same amount of pure aflatoxin had no effect [29]. A 1979 study showed that a dairy herd exposed to contaminated maize (120 ppb) for several months had severe health problems, including the birth of small and unhealthy calves, diarrhoea, acute mastitis, respiratory problems, rectal prolapse and hair loss. Milk production was decreased by $28 \%$ and breeding efficiency by $2 \%$ [30]. A review by Gallo summarises four earlier studies, all showing decreased milk yield in cattle as a result of aflatoxin exposure [31].

Many aflatoxin exposure studies in dairy cattle have aimed to determine carryover rates to milk or to determine the presence and levels of aflatoxin $\mathrm{M}_{1}\left(\mathrm{AFM}_{1}\right)$ in milk. The results show that the amount of $\mathrm{AFM}_{1}$ excreted in milk is around $1-7 \%$ of the total amount of $\mathrm{AFB}_{1}$ ingested [32,33]. Higher levels were seen in high yielding cows. However, in EAC, average milk yields are low [21]. The threshold for aflatoxin excretion in cows' milk is $15 \mathrm{ppb}$ in their feed [34].

\section{Chickens}

Overall, studies in chickens found that experimental feeding of aflatoxins reduced body weight, feed conversion efficiency, average daily gain and feed conversion ratios (Table 1). Broilers were more susceptible than layers $[35,36]$. Productivity losses in commercial broiler operations can occur when aflatoxin concentrations are below those levels of concern established by research in laboratory situations [37]. A case study in South Africa found that broiler houses with poor growth and ascites had consistently higher levels of aflatoxin in feed than samples from broiler houses without problems (18 ppb versus $9 \mathrm{ppb}$ ) [38]. A meta-analysis of studies done on the effect of aflatoxins on growth performance found that, for every $1000 \mathrm{ppb}$ increase of aflatoxin in the diet, the growth rate in broilers would be reduced by 5\% [36]. In laying hens, aflatoxin consumption is associated with reduction in egg production, egg weight and yolk weight as well as changes in yolk colour, shell weight and shell integrity [6].

In chickens, impaired immune response can occur at levels that have no effect on growth rate [39]. Experimental studies found that exposure of chickens to $200 \mathrm{ppb}$ aflatoxin in feed in conjunction with vaccination against Newcastle disease and two other commonly used vaccines resulted in lack of adequate protection against subsequent experimental exposure to disease [40]. The interaction of infectious bursal disease (IBD) and aflatoxicosis led to an increased mortality of $35.6 \%$ when compared to 3-21\% mortality with IBD alone and $0.03 \%$ mortality with aflatoxicosis alone [41].

\section{Other poultry}

Turkeys and ducks are highly susceptible to aflatoxins, more so than chickens. A review of several studies reported that the $\mathrm{AFB}_{1}$ contamination level needed to impair production was $800 \mathrm{ppb}$ in chickens, $700 \mathrm{ppb}$ in geese and quail, $500 \mathrm{ppb}$ in ducks and $400 \mathrm{ppb}$ in 


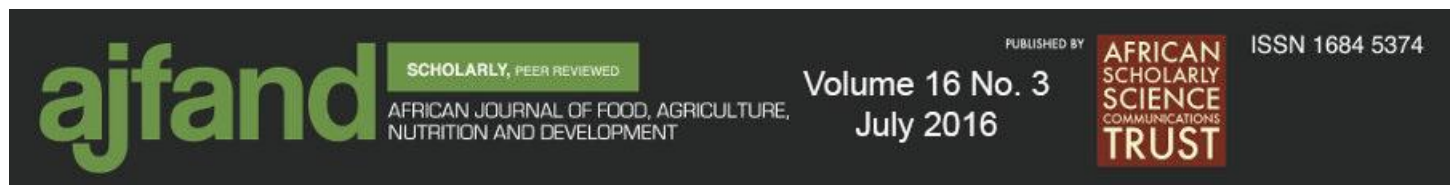

turkeys [42]. Turkey X disease (caused by aflatoxins in imported feed), appears to have led to salmonellosis and candidiasis outbreaks [43]. Dietary aflatoxins caused liver damage in ducks while no damage was recorded in chickens [44]. In Zimbabwe, 70 ostriches died after being fed aflatoxin-contaminated commercial pelleted feed. Samples found levels of 11, 55, 98 and $129 \mathrm{ppb}$, suggesting ostriches are more susceptible to aflatoxins than chickens [45]. Quail appear more susceptible than chickens [42]. In one experiment, laying quail were fed 25,50 or $100 \mathrm{ppb}$ of aflatoxin. Average weight and egg production were not affected but in groups receiving $50 \mathrm{ppb}$ and above, egg weight was lower, while liver lesions were seen at $200 \mathrm{ppb}$ [46].

\section{Pigs}

Pigs are highly susceptible to aflatoxins. Clinical signs of acute aflatoxicosis include anorexia, nervous signs and sudden death [47]. Acute and peri-acute signs were evident after pigs ingested peanut screenings contaminated with $22,000 \mathrm{ppb}$ aflatoxin, while subacute aflatoxicosis due to ingestion of sorghum with levels of $4640 \mathrm{ppb}$ led to death in weeks [48]. Experimental intoxications have shown damaged white blood cells in piglets, indicating a loss of immune competence [49].

Studies on pigs show reduced weight gain and feed conversion ratios to different extent (Table 2). A meta-analysis of experimental studies in swine reviewed 85 articles published between 1968 and 2010 [50]. Aflatoxin effects were greater in younger animals and at higher doses. For each additional $1000 \mathrm{ppb}$ of aflatoxin in the feed, there was a reduction of $3.9 \%$ in pig weight gain. The authors also reported methionine and protein were protective, improving the feed intake and the weight gain in challenged animals. Another meta-analysis of studies done on the effect of aflatoxins on growth performance in pigs found that for every $1000 \mathrm{ppb}$ increase of aflatoxin in the diet, the growth rate in pigs would be reduced by $16 \%$ [36]. Additionally, in this study, dietary concentrations that would cause a 5\% reduction in growth rate were estimated at $300 \mathrm{ppb}$ for pigs. Aflatoxin $\mathrm{B}_{1}, \mathrm{AFG}_{1}$ and $\mathrm{AFM}_{1}$ can be present in the sow's milk and different levels are possible depending on the initial contamination of the feed [47].

\section{Sheep}

Lewis et al. [51] showed that feeding sheep $1750 \mathrm{ppb}$ aflatoxins for 3.5 years led to nasal and liver tumours in three out of eight sheep. A study in Nigeria exposed West African dwarf goats to $0,50,100$ and $150 \mathrm{ppb}$ of aflatoxins and found dose dependent decreases in weight gain, concentrate intake, feed conversion ratios and mortality [52].

\section{Aquatic species}

Fish vary in susceptibility to aflatoxins but toxic signs such as feed refusal, jaundice, weight loss, feed efficiency reduction, liver dysfunction and cellular damage are commonly observed [53]. Nile tilapia is widely farmed in tropical and subtropical regions. There have been several studies on the impact of aflatoxin consumption and growth rates, with variable results. A diet with $100 \mathrm{ppb}$ for ten weeks significantly reduced growth [54], yet a diet with $250 \mathrm{ppb}$ led to no adverse effects [55]. More recent, larger and longer term trials show no difference in weight gain at $85 \mathrm{ppb}$ but significantly less weight gain at $245 \mathrm{ppb}$ and above [56]. 


\section{Honeybees}

Honeybees are relatively resistant to aflatoxins. One study found $1000 \mathrm{ppb}$ and $2500 \mathrm{ppb}$ diet of $\mathrm{AFB}_{1}$ did not have any apparent toxic effects on bees. A higher dose of $5000 \mathrm{ppb}$ caused less than $50 \%$ mortality after 72 hours. Doses of $\mathrm{AFB}_{1}$ above 10,000 ppb caused over $90 \%$ mortality in 72 hours [57]. Fresh honey collected in Palestine was contaminated with aflatoxins at levels ranging from $0.5-22 \mathrm{ppb}$ [58]. The origin of contamination was not determined, but the research showed that honeybees can be naturally affected by aflatoxins.

\section{Livestock feeds}

Only a small number of studies were identified from East Africa. Studies from Kenya found that feed samples were contaminated with aflatoxin ranging from 5.13-1123 ppb $[59,60]$. One three-year study found only $5 \%$ of samples were below the regulatory limit of $10 \mathrm{ppb}$ and $35 \%$ of feed samples had more than $100 \mathrm{ppb}$ [61]. A survey in Tanzania found broiler feed samples had on average $36 \mathrm{ppb}$ aflatoxins and layer feed $15 \mathrm{ppb}$ [62]. A recent study from Ethiopia sampled cattle feed from peri-urban Addis Ababa. Out of a total of 156 feed samples collected, only $16(10 \%)$ contained $\mathrm{AFB}_{1}$ at a level less than or equal to $10 \mathrm{ppb}$, while $26 \%$ exceeded $100 \mathrm{ppb}$ [63].

In East Africa, as elsewhere, maize is an important component of poultry feed. Dairy feed sources appear to be more diverse and, at least in Ethiopia, maize is used less often [63]. There are several reports on aflatoxin contamination of maize in East Africa but presence in maize is not a good indicator of presence in feed because (a) some farmers are known to channel worst quality maize to animal feed and (b) some feed manufacturers may test for aflatoxin.

\section{Animal source foods}

A limited number of surveys in East Africa have assessed aflatoxin levels in milk. Across five papers reviewed, aflatoxin was detected in $45-100 \%$ of milk samples and in all surveys some samples had levels exceeding $0.05 \mathrm{ppb}$ [59-61, 63, 64], the European Union standard for acceptable aflatoxin levels in milk. No studies were found that assessed the aflatoxin levels in eggs or meat in East Africa.

\section{DISCUSSION}

This wide-ranging review allows some broad conclusions to be drawn, which can inform strategies to address the problems of livestock production in sub-Saharan Africa. Consumption of aflatoxins by livestock and fish seriously reduces their productivity. Chronic aflatoxicosis probably has greater economic impacts than acute disease, as acute disease has never been reported but livestock are exposed to un-controlled aflatoxin through feed. Typically, animals show a worsening in feed conversion ratio, a decrease in average daily gain and decrease in body weight for animals experimentally fed aflatoxins; this has been reported by other reviews [65].

Different species differ widely in their susceptibility to aflatoxins. The age of the animals also plays an important role. Therefore, management should be differentiated by species, 
age and other relevant factors. Generalising across the papers we identified, dietary levels of aflatoxin (in ppb) generally tolerated are $\leq 50$ in young poultry, $\leq 100$ in adult poultry, $\leq 50$ in weaned pigs, $\leq 200$ in finishing pigs, $<100$ in calves, $<300$ in cattle and $<100$ in Nile tilapia. However, ill effects may be observed at lower levels, especially if animals are exposed to other stressors. Conversely, in other studies reviewed, no ill effects were evident at considerably higher levels. As mentioned, mycotoxins may interact and therefore health effects can be difficult to predict based only on studies of aflatoxins. Papers reviewed also suggested that the decrease in body weight due to aflatoxin exposure can be partially improved by exercise, increased dietary protein, increased dietary methionine and good environmental conditions.

This literature review also shows some inconsistencies between studies. Some studies show impacts in commercial herds/flocks at levels below those shown to cause impacts in laboratory trials. Some studies show impacts at low levels of aflatoxins while others do not show impacts even at high levels. In the first case, this could be because animals are exposed to multiple stressors in real life and could also be ingesting a mixture of mycotoxins. Confounding factors may include food quality, exercise, breed and age of animals or the trials being too short or having too few animals to detect any clinical effects.

Nearly 18 million poultry and over five million dairy cattle in East Africa are dependent on livestock feed. Yet few studies have examined aflatoxin contamination of feeds in East Africa. The limited information suggests a substantial proportion of this feed is contaminated at levels likely to reduce milk, egg and poultry meat production. Aflatoxin levels in milk are also of concern especially because milk consumption is often higher among infants and children, who are likely to be more vulnerable.

\section{THE WAY FORWARD}

As livestock systems intensify, problems with aflatoxins are likely to worsen. This could be compounded if the larger regulatory framework to address aflatoxin in the human food supply is strengthened, possibly resulting in an increased flow of rejected and highly contaminated grains entering the commercial and informal feed supply chains. In East Africa, livestock are often subject to other stressors such as disease and malnutrition, making them more vulnerable to disease and enhancing the effects of aflatoxins.

Even though there are relatively few studies on feed and animal source foods in East Africa, evidence suggests that aflatoxins are a problem in the livestock sector. However, to characterize the extent of the problem and its trends, further information is needed. This could be obtained through prevalence surveys to assess the extent of feed contamination, epidemiological studies to measure the impact on animal health and productivity, risk assessments to estimate the danger posed to human health by aflatoxin residues in milk and other animal source foods, and spatial mapping of aflatoxin prevalence and risk factors.

In parallel with these studies, better evidence is needed on the most appropriate management of aflatoxins in the livestock and aquaculture sectors. There are several 


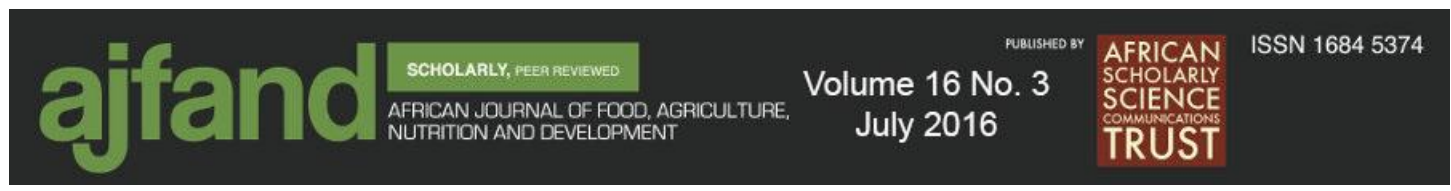

technical options including biological control, testing feedstuffs, aflatoxin binders, antifungal agents, blending down and directing contaminated feed to least susceptible animals [3]. Longer-term options include breeding for resistance in animals and breeding for lower susceptibility in crops [3]. Other institutional approaches focus on policy change, regulation implementation, improved testing or market-based approaches [66]. However, there is little evidence on the efficacy, sustainability, costs and benefits of proposed interventions under conditions unique to sub-Saharan Africa. Furthermore, the policy environment is not enabling within many countries. Operational research into these and other management options can be done in parallel with studies to better characterize the problem and initiatives to create a more enabling policy environment.

Also of importance is a better understanding of the role of livestock and aquaculture to supply essential macronutrients and micronutrients for public health, especially among vulnerable groups, whose nutritional status and food security can either be enhanced or eroded under various new regimes to address aflatoxin contaminated feeds and animal by-products.

Globally, aflatoxins are considered the most important contaminant of animal feed. Evidence is emerging that they are also a problem in East Africa. Understanding the risks associated with aflatoxins and the best ways to mitigate them will be important to the development of East Africa's burgeoning livestock sector.

\section{ACKNOWLEDGEMENTS}

The CGIAR Research Program on Agriculture for Nutrition and Health, led by the International Food Policy Research Institute, and the International Institute of Tropical Agriculture. 


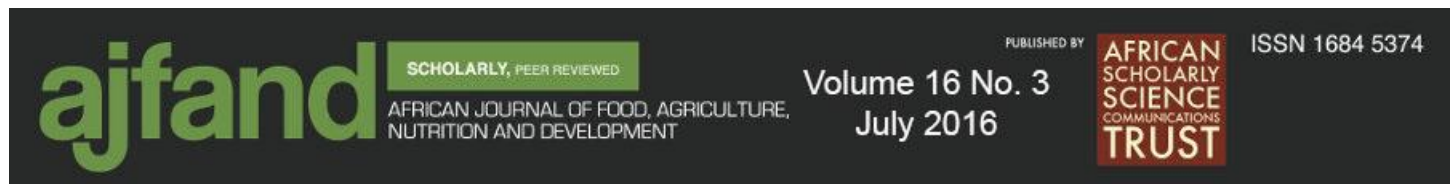

Table 1: Published studies on the impact of aflatoxins in chickens on feed conversion ratio (FCR) and average daily weight gain (ADG)

\begin{tabular}{|c|c|c|c|}
\hline Animal & $\begin{array}{c}\text { Aflatoxin dose and duration of } \\
\text { experiment }\end{array}$ & Results & Study \\
\hline $\begin{array}{l}\text { Chickens } \\
(n=900)\end{array}$ & $\begin{array}{l}0(\mathrm{~A}), 300(\mathrm{~B}), 1250(\mathrm{C}) 2000(\mathrm{D}) \\
\mathrm{ppb} \text { for } 28 \text { days }\end{array}$ & $\begin{array}{l}\text { Decrease in body weight and food intake. Increase } \\
\text { in FCR }(p<0.001)\end{array}$ & [66] \\
\hline $\begin{array}{l}\text { Broiler chicks } \\
(n=40-48)\end{array}$ & $\begin{array}{l}0(A), 5000 \mathrm{ppb} \text { feed }(B) \text {, exercise } \\
\text { only }(C), 5000 \mathrm{ppb} \text { feed + exercise } \\
\text { (D) for } 24 \text { days }\end{array}$ & $\begin{array}{l}\text { Decrease in body weight in aflatoxin-treated group } \\
\text { which can be partially improved by exercise } \\
\text { ( } p<0.01 \text { between birds fed aflatoxins and control). } \\
\text { Increase in FCR in aflatoxin treated group. }\end{array}$ & [67] \\
\hline $\begin{array}{l}\text { Layer chicks } \\
(n=40-48)\end{array}$ & $\begin{array}{l}0(A), 5000 \mathrm{ppb} \text { feed }(B) \text {, exercise } \\
\text { only }(\mathrm{C}), 5000 \mathrm{ppb} \text { feed + exercise } \\
\text { (D) for } 33 \text { days }\end{array}$ & $\begin{array}{l}\text { Decrease in body weight in aflatoxin-treated group, } \\
\text { which can be partially improved by exercise } \\
\text { ( } p<0.01 \text { between birds fed aflatoxins and control). } \\
\text { Increase in FCR in aflatoxin treated group. }\end{array}$ & [67] \\
\hline $\begin{array}{l}\text { Broiler chicks } \\
(n=40-48)\end{array}$ & $\begin{array}{l}0(A), 5000 \mathrm{ppb} \text { feed }(B) \text {, exercise } \\
\text { only }(C), 5000 \mathrm{ppb} \text { feed + exercise } \\
\text { (D) for } 39 \text { days }\end{array}$ & $\begin{array}{l}\text { Decrease in body weight in aflatoxin-treated group, } \\
\text { which can be partially improved by exercise. No } \\
\text { difference in FCR. }\end{array}$ & [67] \\
\hline $\begin{array}{l}\text { Broiler chickens } \\
(n=75)\end{array}$ & $\begin{array}{l}0(\mathrm{~A}), 75 \mathrm{ppb}(\mathrm{B}), 225 \mathrm{ppb}(\mathrm{C}) \text { and } \\
675 \mathrm{ppb}(\mathrm{D}) \text { feed for seven weeks }\end{array}$ & $\begin{array}{l}\text { Decrease in body weight in all aflatoxin-treated } \\
\text { groups }(p<0.05)\end{array}$ & [68] \\
\hline $\begin{array}{l}\text { Broiler } \\
\text { chickens } \\
(n=75)\end{array}$ & $\begin{array}{l}0(A), 300(B), 900(C) \text { and } 2700 \\
\text { (D) ppb feed for seven weeks }\end{array}$ & $\begin{array}{l}\text { Decrease in body weight in only } 2700 \mathrm{ppb} \text { feed } \\
\text { group }(p<0.05)\end{array}$ & [68] \\
\hline $\begin{array}{l}\text { One-day-old } \\
\text { broilers } \\
(n=70)\end{array}$ & $\begin{array}{l}0(A), 625(B), 1250(C), 2500(D) \\
5000(E) \text { and } 10,000(F) \text { ppb feed } \\
\text { for three weeks }\end{array}$ & $\begin{array}{l}\text { Aflatoxin dose-dependent decrease in body weight } \\
\text { at the dose } 1250 \mathrm{ppb} \text { and higher }(p<0.05)\end{array}$ & [69] \\
\hline $\begin{array}{l}\text { Day-old chicks } \\
(n=120)\end{array}$ & $\begin{array}{l}0(A), 2500(B), 5000(C), \text { and } \\
10,100(D) p p b \text { feed for four weeks }\end{array}$ & $\begin{array}{l}\text { Aflatoxin dose-dependent decrease in body weight } \\
(p>0.05)\end{array}$ & [70] \\
\hline $\begin{array}{l}\text { One-day-old broiler } \\
\text { and layer chicks } \\
\text { ( } n=40 \text { each) }\end{array}$ & $\begin{array}{l}0(\mathrm{~A}), 1000(\mathrm{~B}) \text { and } 4000(\mathrm{C}) \mathrm{ppb} \\
\text { feed for four weeks }\end{array}$ & $\begin{array}{l}\text { Aflatoxin dose-dependent decrease in body weight } \\
(p>0.05)\end{array}$ & [71] \\
\hline
\end{tabular}




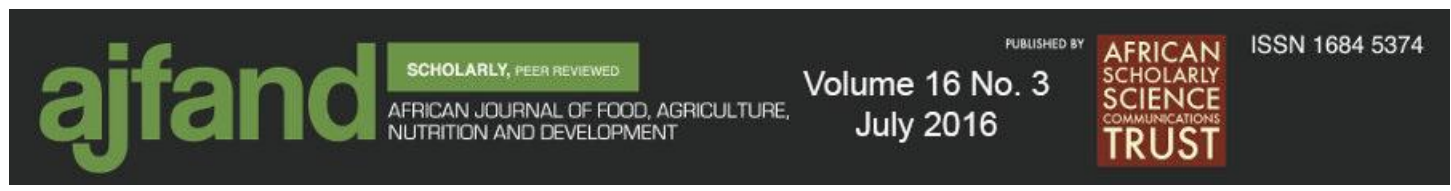

Table 2: Published studies on the impact of aflatoxins in pigs on feed conversion rate (FCR), average daily weight gain (ADG) and average daily feed intake (ADFI)

\begin{tabular}{|c|c|c|c|}
\hline Animal & $\begin{array}{l}\text { Aflatoxin dose and } \\
\text { duration of experiment }\end{array}$ & Results & Study \\
\hline $\begin{array}{l}\text { Pigs } \\
(n=50)\end{array}$ & $\begin{array}{l}0(A), 200(B), 700(C) \\
1100(D) \text { ppb feed for } \\
16 \text { weeks }\end{array}$ & $\begin{array}{l}\text { No significant difference in body weight } \\
\text { between groups. } \\
\text { Dose related increase in FCR }(p<.05)\end{array}$ & {$[72]$} \\
\hline $\begin{array}{l}\text { Pigs } \\
(n=60)\end{array}$ & $\begin{array}{l}0(A), 1000(B), 2000(C), 4000 \\
\text { (D) ppb feed for } 13 \text { weeks }\end{array}$ & Dose related increase in FCR $(p<.001)$ & {$[72]$} \\
\hline $\begin{array}{l}\text { Pigs, weanlings } \\
(n=110)\end{array}$ & $\begin{array}{l}<2(A),<8(B), 51(C), 105(D) \\
233(E) \text { ppb feed for } 120 \text { days }\end{array}$ & $\begin{array}{l}\text { No significant effect on weight gain or feed } \\
\text { conversion }\end{array}$ & [73] \\
\hline $\begin{array}{l}\text { Pigs, weanlings } \\
(n=110)\end{array}$ & $\begin{array}{l}<6(A), 45(B), 615(C), 810(D) \\
\text { ppb feed for } 120 \text { days }\end{array}$ & $\begin{array}{l}\text { Decrease in ADG at the dose of } 615 \text { and } 810 \\
\text { ppb feed }(p<.05)\end{array}$ & [73] \\
\hline Pigs $(n=32)$ & $\begin{array}{l}20(\mathrm{~A}), 385(\mathrm{~B}), 750(\mathrm{C}), 1480 \\
\text { (D) ppb in feed } \\
\text { (control: } 20 \mathrm{ppb} \text { group) }\end{array}$ & $\begin{array}{l}\text { Dose related decrease in ADG and ADFI } \\
(p<.05) \\
\text { Increase in FCR in the } 1480 \text { ppb group }(p<.05)\end{array}$ & [74] \\
\hline $\begin{array}{l}\text { Pigs, } 5-6 \text { week } \\
\text { old }(n=30)\end{array}$ & $\begin{array}{l}0(\mathrm{~A}), 300(\mathrm{~B}) \text { and } 500(\mathrm{C}) \mathrm{ppb} \\
\text { feed for } 10 \text { weeks }\end{array}$ & $\begin{array}{l}\text { Decrease in weight gain and feed } \\
\text { consumption in high-dose group compared } \\
\text { with controls }(p<.01)\end{array}$ & {$[75]$} \\
\hline $\begin{array}{l}\text { Pigs, weanlings } \\
(n=90)\end{array}$ & $\begin{array}{l}0(\mathrm{~A}), 420(\mathrm{~B}), 840(\mathrm{C}) \mathrm{ppb} \text { feed } \\
\text { for } 49 \text { days }\end{array}$ & $\begin{array}{l}\text { Decrease in ADG and increase in FCR } \\
(p<.01)\end{array}$ & [76] \\
\hline $\begin{array}{l}\text { Pigs, weanlings } \\
(n=63)\end{array}$ & $\begin{array}{l}0(\mathrm{~A}) \text { and } 800(\mathrm{~B}) \mathrm{ppb} \\
\text { feed for } 42 \text { days }\end{array}$ & Decrease in ADG & [76] \\
\hline $\begin{array}{l}\text { Pigs, weanlings } \\
(n=96)\end{array}$ & $\begin{array}{l}0(\mathrm{~A}) \text { and } 992(\mathrm{~B}) \mathrm{ppb} \text { feed for } 6 \\
\text { weeks }\end{array}$ & Decrease in ADG $(p<.01)$ & [77] \\
\hline $\begin{array}{l}\text { Pigs, weaned } \\
(n=54)\end{array}$ & $\begin{array}{l}0(\mathrm{~A}) \text { and } 880(\mathrm{~B}) \mathrm{ppb} \\
\text { feed for } 4 \text { weeks }\end{array}$ & $\begin{array}{l}\text { Decrease in ADG and ADFI }(p<.05) \\
\text { Increase in FCR }(p<.05)\end{array}$ & {$[78]$} \\
\hline $\begin{array}{l}\text { Pigs, weaned } \\
(n=81)\end{array}$ & $\begin{array}{l}0(A) \text { and } 500(B) p p b \\
\text { feed for } 5 \text { weeks }\end{array}$ & Decrease in ADG and ADFI $(p<.05)$ & [78] \\
\hline $\begin{array}{l}\text { Pigs, weaned } \\
(n=63)\end{array}$ & $\begin{array}{l}0(\mathrm{~A}) \text { and } 800(\mathrm{~B}) \mathrm{ppb} \text { feed for } 4 \\
\text { weeks }\end{array}$ & Decrease in ADG $(p<.05)$ and ADFI $(p<.01)$ & {$[78]$} \\
\hline $\begin{array}{l}\text { Pigs, growing } \\
\text { barrow } \\
(\mathrm{n}=40)\end{array}$ & $\begin{array}{l}0(\mathrm{~A}) \text { and } 3000(\mathrm{~B}) \mathrm{ppb} \text { feed for } \\
28 \text { days }\end{array}$ & Decrease in weight gain $(p<.05)$ & [79] \\
\hline $\begin{array}{l}\text { Pigs } \\
(n=27)\end{array}$ & $\begin{array}{l}0(\mathrm{~A}), 2500 \mathrm{ppb} \text { feed (B), } 2500 \\
\mathrm{ppb} \text { feed }+2400 \mathrm{IU} \text { tocopherol } \\
\text { (C) for } 32 \text { days }\end{array}$ & $\begin{array}{l}\text { Decrease in bodyweight } \\
\text { feed consumption }(p<.05)\end{array}$ & {$[80]$} \\
\hline $\begin{array}{l}\text { Pigs } \\
(n=18)\end{array}$ & $\begin{array}{l}0(\mathrm{~A}), 2500 \mathrm{ppb} \text { feed (B), } 2500 \\
\mathrm{ppb} \text { feed }+100 \mathrm{mg} \\
\text { fumonisin B1/kg feed (C) for } 35 \\
\text { days }\end{array}$ & $\begin{array}{l}\text { Decrease in bodyweight, weight gain and feed } \\
\text { consumption }\end{array}$ & [81] \\
\hline $\begin{array}{l}\text { Pigs, } 4 \text { week } \\
\text { old weaned } \\
(n=36)\end{array}$ & $\begin{array}{l}0(\mathrm{~A}), 240(\mathrm{~B}), 480(\mathrm{C}) \mathrm{ppb} \text { feed } \\
\text { for } 30 \text { days }\end{array}$ & Decrease in ADG $(p<.05)$ & [49] \\
\hline
\end{tabular}




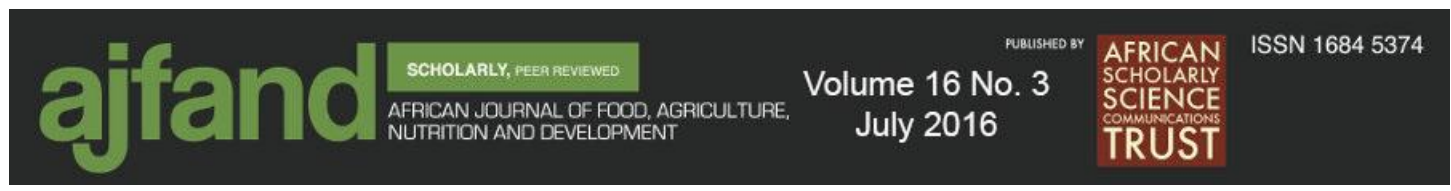

\section{REFERENCES}

1. Food and Agriculture Organization of the United Nations (FAO) Mapping Supply and Demand for Animal-Source Foods to 2030. Animal Production and Health Working Paper No. 2. FAO, Rome, 2011.

2. Pitt JI, Wild CP, Baan RA, Gelderblom WCA, Miller JD, Riley RT and F Wu Improving Public Health through Mycotoxin Control. IARC Scientific Publication No. 158. World Health Organization (WHO), Geneva, 2012.

3. Unnevehr $\mathbf{L}$ and D Grace Aflatoxins: Finding Solutions for Improved Food Safety. IFPRI 2020 Focus Brief No. 20. IFPRI, Washington, DC, 2013.

4. Scudamore KA. Aspergillus toxins in food and animal feedingstuffs. In: Powell KA, Renwick A and JF Peberdy (Eds). The Genus Aspergillus. Springer US, New York, 1994: 59-71.

5. Wolzak A, Pearson A and T Coleman Aflatoxin carryover and clearance from tissues of laying hens. Food Chem. Toxicol. 1986; 24(1): 37-41.

6. Zaghini A, Martelli G, Roncada P, Simioli $M$ and $L$ Rizzi Mannanoligosaccharides and Aflatoxin B1 in Feed for Laying Hens: Effects on Egg Quality, Aflatoxins B1 And M1 Residues in Eggs, and Aflatoxin B1 Levels in Liver. Poult. Sci. 2005; 84(6): 825-832.

7. Grace D Animals and Aflatoxins. In: Unnevehr L and D Grace (Eds). Aflatoxins: Finding Solutions for Improved Food Safety. IFPRI, Washington DC, 2013: Brief 5 .

8. Gong YY, Hounsa A, Egal S, Turner PC, Sutcliffe AE, Hall AJ, Cardwell K and CP Wild Postweaning Exposure to Aflatoxin Results in Impaired Child Growth: A Longitudinal Study in Benin, West Africa. Environ. Health Perspect. 2004; 112(13): 1334-1338.

9. Turner PC, Moore SE, Hall AJ, Prentice AM and CP Wild Modification of immune Function Through Exposure to Dietary Aflatoxin in Gambian Children. Environ. Health Perspect. 2003; 111: 217-220.

10. Kuniholm MH, Lesi OA, Mendy M, Akano AO, Sam O, Hall AJ, Whittle H, Bah E, Goedert JJ, Hainaut $\mathbf{P}$ and GD Kirk Aflatoxin Exposure and Viral Hepatitis in the Etiology of Liver Cirrhosis in the Gambia, West Africa. Environ. Health Perspect 2008; 116(11): 1553-1557.

11. Ibeh IN, Uraih N and JI Ogonar Dietary Exposure to Aflatoxin in Human Male Infertility in Benin City, Nigeria. Int. J. Fertil. Menopausal Stud. 1994; 39: 208214. 


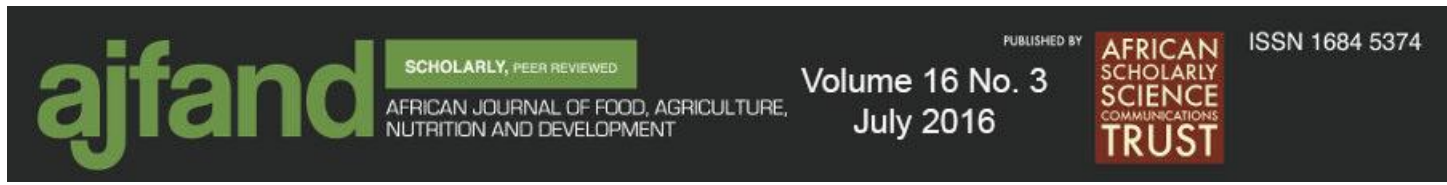

12. Egal S, Hounsa A, Gong YY, Turner PC, Wild CP, Hall AJ, Hell K and KF Cardwell Dietary Exposure to Aflatoxin from Maize and Groundnut in Young Children from Benin and Togo, West Africa. Int. J. Food Microbiol. 2005; 104(2): 215-224.

13. Gong YY, Cardwell KF, Hounsa A, Egal S, Turner PC, Hall AJ and CP Wild Dietary Aflatoxin Exposure and Impaired Growth in Young Children from Benin and Togo: Cross Sectional Study. Br. Med. J. 2002; 325(7354): 20-21.

14. Okoth SA and M Ohingo Dietary Aflatoxin Exposure and Impaired Growth in Young Children from Kisumu District, Kenya: Cross Sectional Study. Afr. J. Health Sci. 2004; 11: 43-54.

15. Homei A and M Worboys Fungal Disease in Britain and the United States 1850 2000: Mycoses and Modernity. Palgrave Macmillan, UK, 2013.

16. Council of Agricultural Science \& Technology Mycotoxins: Risks in Plant, Animal and Human Systems. Task Force Report No. 139. Council of Agricultural Science \& Technology, Iowa, USA, 2003.

17. Azziz-Baumgartner E, Lindblade K, Gieseker K, Rogers HS, Kieszak S, Njapau H, Schleicher R, McCoy LF, Misore A, DeCock K, Rubin C, Slutsker $\mathbf{L}$ and Aflatoxin Investigative Group Case-control Study of an Acute Aflatoxicosis Outbreak, Kenya, 2004. Environ. Health Perspect. 2005; 113: $1779-1783$.

18. Feddern V, Dors GC, Tavernari F de C, Mazzuco H, Cunha A, Krabbe EL and GN Scheuermann Aflatoxins Importance on Animal Nutrition. In: Razzaghi-Abyaneh M (Ed). Aflatoxins: Recent Advances and Future Prospects. Rijeka, Croatia: InTech, 2013: 171-195.

19. International Agency for Research on Cancer (IARC) IARC Monographs on the Evaluation of Carcinogenic Risks To Humans. IARC Monographs, Vol. 100. WHO, Geneva, 2002.

20. Moher D, Liberati A, Tetzlaff J, Altman DG and The PRISMA Group Preferred Reporting Items for Systematic Reviews and Meta-analyses: The PRISMA Statement. PLOS Med. 2009; 6(7): e1000097.

21. Kang'ethe E, Grace D, Lindahl J and C Atherstone Situational Analysis: Animal Health and Aflatoxin in the East African Region. Kigali, Rwanda; 2014.

22. Uganda Bureau of Statistics National Livestock Census. Uganda Bureau of Statistics, Kampala. 2008: 1-32.

23. Ouma E, Dione M, Lule P, Roesel $\mathbf{K}$ and $\mathbf{D}$ Pezo Characterization of smallholder pig production systems in Uganda: Constraints and opportunities for engaging with market systems. Livestock Res. Rural Dev. 2014; 26(3): 56. 


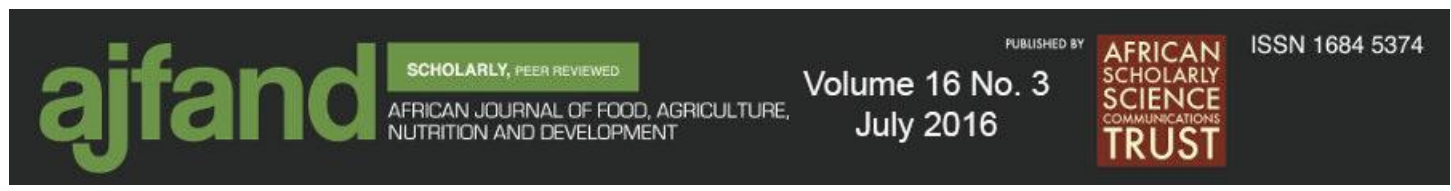

24. Muriuki HG Dairy Development in Kenya. FAO, Rome, 2011.

25. Tanzania Ministry of Livestock and Fisheries Development Investment Opportunities in the Livestock Industry. Government of Tanzania, Dar es Salaam, 2011.

26. Food and Agriculture Organization of the United Nations (FAO) Poultry Sector Country Review: Uganda. FAO, Rome, 2008.

27. Graffham A, Kleih U, Jagwe J, Nabawanuka J, Wanda K, Kalunda P, Ntibarikure G and S Ferris A Market Opportunities Survey for Value-Added Utilization of Cassava-Based Products in Uganda Part 1: Demand Analysis For Industrial Utilization. ASARECA/IITA Monograph 3. IITA, Ibadan, 2003.

28. Mwanzia R Kenya Poultry Update. Kenya Poultry Partnership. 2010.

29. Applebaum RS, Brackett RE, Wiseman DW and EH Marth Responses of Dairy Cows to Dietary Aflatoxin: Feed Intake and Yield, Toxin Content, and Quality of Milk of Cows Treated with Pure and Impure Aflatoxin. J. Dairy Sci. 1982; 65(8): 1503-1508.

30. Guthrie LD and DM Bedell Effects of Aflatoxin in Corn on Production and Reproduction in Dairy Cattle. Proc. Annu. Meet. U.S. Anim. Health Assoc. 1979; (83): 202-204.

31. Gallo A, Giuberti G, Frisvad J, Bertuzzi $\mathbf{T}$ and $\mathbf{K}$ Nielsen Review on Mycotoxin Issues in Ruminants: Occurrence in Forages, Effects of Mycotoxin Ingestion on Health Status and Animal Performance and Practical Strategies to Counteract Their Negative Effects. Toxins (Basel) 2015; 7(8): 3057-3111.

32. Egmond HP van Aflatoxin M1: Occurrence, Toxicity, Regulation. In: Egmond HP van (Ed). Mycotoxins in Dairy Production. London, UK and New York, NY: Elsevier Applied Science, 1989: 11-55.

33. Veldman A, Meijs JAC, Borggreve GJ and JJ Heeres-van der Tol Carry-over of Aflatoxin from Cows' Food to Milk. Anim. Prod. 1992; 55(02): 163-168.

34. Coppock RW and RG Christian Aflatoxins. In: Gupta RC. (Ed). Veterinary Toxicology: Basic and Clinical Principles. Amsterdam, Elsevier, 2012: 939-950.

35. Huff WE, Kubena LF, Harvey RB, Hagler Jr WM, Swanson SP, Phillips TD and CR Creger Individual and Combined Effects of Aflatoxin and Deoxynivalenol (DON, Vomitoxin) in Broiler Chickens. Poultry Sci. 1986; 65(7): 1291-1298.

36. Dersjant-Li Y, Verstegen MWA and WJJ Gerrits The Impact of Low Concentrations of Aflatoxin, Deoxynivalenol or Fumonisin in Diets on Growing Pigs and Poultry. Nutr. Res. Rev. 2003; 16(2): 223-239. 


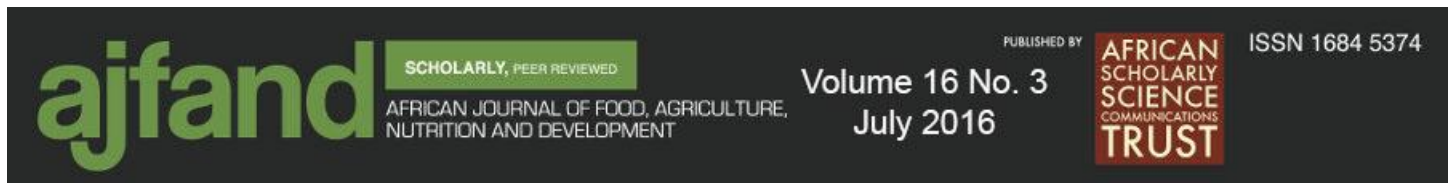

37. Jones FT, Hagler WH and PB Hamilton Association of Low Levels of Aflatoxin in Feed with Productivity Losses in Commercial Broiler Operations. Poultry Sci. 1982; 61(5): 861-868.

38. Westlake K and MMF Dutton The Incidence of Mycotoxins in Litter, Feed, and Livers of Chickens in Natal. S. Afr. J. Anim. Sci. 1985; 15(4): 4-6.

39. Smith JW and PB Hamilton Aflatoxicosis in the Broiler Chicken. Poultry Sci. 1970; 49(1): 207-215.

40. Gabal MA and AH Azzam Interaction of Aflatoxin in the Feed and Immunization Against Selected Infectious Diseases in Poultry. II. Effect on Oneday-old Layer Chicks Simultaneously Vaccinated against Newcastle Disease, Infectious Bronchitis and infectious Bursal Disease. Avian Pathol. 1998; 27(3): 290-295.

41. Otim MO, Mukiibi-Muka G, Christensen $\mathbf{H}$ and $\mathbf{M}$ Bisgaard Aflatoxicosis, Infectious Bursal Disease and Immune Response to Newcastle Disease Vaccination in Rural Chickens. Avian Pathol. 2005; 34(4): 319-323.

42. Monson MS, Coulombe RA and KM Reed Aflatoxicosis: Lessons from Toxicity and Responses to Aflatoxin $\mathrm{B}_{1}$ in Poultry. Agriculture 2015; 5(3): $742-$ 777.

43. Siller W and D Ostler The Histopathology of an Enterohepatic Syndrome of Turkey Poults. Vet. Rec. 1961; 73: 134-138.

44. Ostrowski-Meissner HT Effect of Contamination of Diets with Aflatoxins on Growing Ducks and Chickens. Trop. Anim. Health Prod. 1983; 15(3): 161-168.

45. Siwela AH and N Nziramasanga Regulatory Aspects of Aflatoxin Control in Zimbabwe - A Review. J. Appl. Sci. S. Afr. 1999; 5(2): 141-147.

46. Oliveira CAF, Rosmaninho JF, Butkeraitis P, Corrêa B, Reis TA, Guerra JL, Albuquerque R and MEG Moro Effect of Low Levels of Dietary Aflatoxin $B_{1}$ on Laying Japanese Quail. Poultry Sci. 2002; 81(7): 976-980.

47. Kanora A and D Maes The Role of Mycotoxins in Pig Reproduction: A Review. Vet. Med. (Praha) 2009; 54(12): 565-576.

48. Ketterer PJ, Blaney BJ, Moore CJ, McInnes IS and PW Cook Field Cases of Aflatoxicosis in Pigs. Aust. Vet. J. 1982; 59(4): 113-117.

49. Marin DE, Taranu I, Bunaciu RP, Pascale F, Tudor DS, Avram N, Sarca M, Cureu I, Criste RD, Suta V and IP Oswald Changes in Performance, Blood Parameters, Humoral and Cellular Immune Responses in Weanling Piglets Exposed to Low Doses of Aflatoxin. J. Anim. Sci. 2002; 80: 1250-1257. 


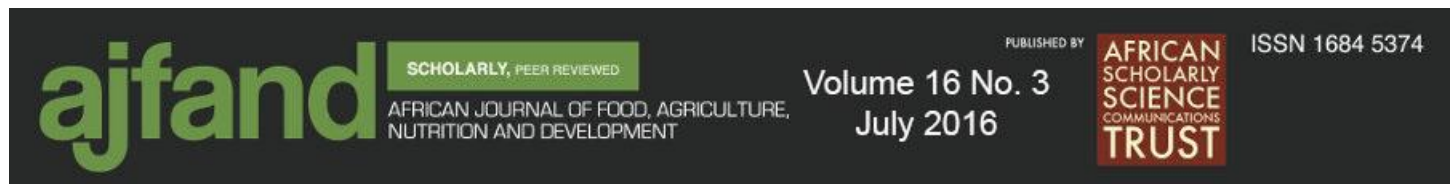

50. Andretta I, Kipper M, Lehnen CR, Hauschild L, Vale MM and PA Lovatto Meta-analytical Study of Productive and Nutritional Interactions of Mycotoxins in Growing Pigs. Animal 2012; 6(9): 1476-1482.

51. Lewis G, Markson $\mathbf{L}$ and $\mathbf{R}$ Allcroft The Effect of Feeding Toxic Groundnut Meal to Sheep Over a Period of Five Years. Vet. Rec. 1967; 80(9): 312-314.

52. Ewuola EO, Jimoh OA and AD Bello Growth Response and Nutrient Digestibility of West African Dwarf Goats Fed Micro Doses of Dietary Aflatoxin. Sci. J. Anim. Sci. 2013; 2(11): 316-322.

53. Santacroce MP, Conversano MC, Casalino E, Lai O, Zizzadoro C, Centoducati $\mathbf{G}$ and $\mathbf{G}$ Crescenzo Aflatoxins in Aquatic Species: Metabolism, Toxicity and Perspectives. Rev. Fish Biol. Fisher. 2007; 18(1): 99-130.

54. El-Banna R, Teleb HM, Hadi MM and FM Fakhry Performance and Tissue Residue of Tilapias Fed Dietary Aflatoxin. Vet. Med. J. Giza 1992; 40(3): 17-23.

55. Tuan NA, Grizzle JM, Lovell RT, Manning BB and GE Rottinghaus Growth and Hepatic Lesions of Nile Tilapia (Oreochromis niloticus) Fed Diets Containing Aflatoxin $\mathrm{B}_{1}$. Aquaculture 2002; 212(1-4): 311-319.

56. Deng SX, Tian LX, Liu FJ, Jin SJ, Liang GY, Yang HJ, Du ZY and YJ Liu Toxic Effects and Residue of Aflatoxin $\mathrm{B}_{1}$ in Tilapia (Oreochromis niloticus x $O$. aureus) During Long-Term Dietary Exposure. Aquaculture 2010; 307(3-4): 233240.

57. Niu G, Johnson RM and MR Berenbaum Toxicity of Mycotoxins to Honeybees and its Amelioration by Propolis. Apidologie 2011; 42(1): 79-87.

58. Swaileh KM and A Abdulkhaliq Analysis of Aflatoxins, Caffeine, Nicotine and Heavy Metals in Palestinian Multifloral Honey from Different Geographic Regions. J. Sci. Food Agric. 2013; 93(9): 2116-2120.

59. Kang'ethe EK and KA Lang'a Aflatoxin $B_{1}$ and $M_{1}$ Contamination of Animal Feeds and Milk from Urban Centers in Kenya. Afr. Health Sci. 2009; 9(4): 218226.

60. Kang'ethe EK, M'Ibui GM, Randolph TF and AK Lang'at Prevalence of Aflatoxin $\mathrm{M}_{1}$ and $\mathrm{B}_{1}$ in Milk and Animal Feeds from Urban Smallholder Dairy Production in Dagoretti Division, Nairobi, Kenya. E. Afr. Med. J. 2007; 84: S83S86.

61. Okoth SA and MA Kola Market Samples as a Source of Chronic Aflatoxin Exposure in Kenya. Afr. J. Health Sci. 2012; 20(1-2): 56-61. 


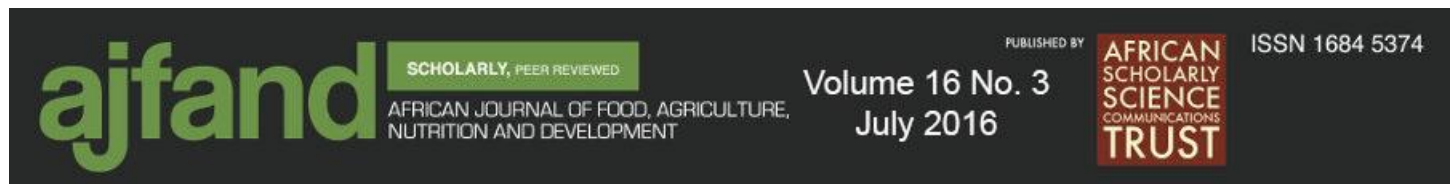

62. Kajuna FF, Temba BA and RD Mosha Surveillance of Aflatoxin $B_{1}$ Contamination in Chicken Commercial Feeds in Morogoro, Tanzania. Livest. Res. Rural Dev. 2013; 25(3): Article \#51.

63. Gizachew D, Szonyi B, Tegegne A, Hanson J and D Grace Aflatoxin Contamination of Milk and Dairy Feeds in the Greater Addis Ababa Milk Shed, Ethiopia. Food Control 2016; 59: 773-779.

64. Urio EM, Juma A, Mwanyika S, Mlingi NV, Ndunguru GT and GD Ndossi The Occurrence of Aflatoxin $\mathrm{M}_{1}$ in Fresh Cow Milk Retailed in Dar es Salaam, Tanzania. In: Njapau, H, Trujillo S, Egmond HP van and DL Park (Eds). Mycotoxins and Phycotoxins: Advances in Determination, Toxicology and Exposure Management. Proceedings of the XIth International IUPAC Symposium on Mycotoxins and Phycotoxins, May 17 - 21, 2004 Bethesda, Maryland, USA. Wageningen: Wageningen Academic Publishers, 2004: 203-208.

65. Khlangwiset $\mathbf{P}$, Shephard GS and $\mathbf{F}$ Wu Aflatoxins and Growth Impairment: A Review. Crit. Rev. Toxicol. 2011; 41(9): 740-755.

66. Bryden WL, Cumming RB and D Balnave The Influence of Vitamin A Status on the Response of Chickens to Aflatoxin $\mathrm{B}_{1}$ and Changes in Liver Lipid Metabolism Associated with Aflatoxicosis. Br. J. Nutr. 1979; 41: 529-540.

67. Randall GM and FH Bird The Effect of Exercise on the Toxicity of Aflatoxin $\mathrm{B}_{1}$ in Chickens. Poultry Sci. 1979; 58: 1284-1288.

68. Doerr JA, Huff WE, Wabeck CJ, Chaloupka GW, May JD and JW Merkley Effects of low Level Chronic Aflatoxicosis in Broiler Chickens. Poultry Sci. 1983; 62: 1971-1977.

69. Huff WE Evaluation of Tibial Dyschondroplasia During Aflatoxicosis and Feed Restriction in Young Broiler Chickens. Poultry Sci. 1980; 59: 991-995.

70. Shukla SK and SP Pachauri Effect of Aflatoxicosis on Growth and Development in Cockerels. Indian Vet. J. 1985; 62: 341-342.

71. Ram K V, Rao DG and PR Rao Effect of Aflatoxin Feeding and its Withdrawal Effect on the Growth-Rate of Broilers and Layers Under Long-term Feeding Trials. Indian Vet. J. 1988; 65: 113-116.

72. Armbrecht BH, Wiseman HG, Shalkop WT and JN Geleta Swine Aflatoxicosis: An Assessment of Growth Efficiency and Other Responses in Growing Pigs Fed Aflatoxin. Environ. Physiol. 1971; 1: 198-208.

73. Keyl AC and AN Booth Aflatoxin Effects in Livestock. J. Am. Oil Chem. Soc. 1971; 48: 599-604. 


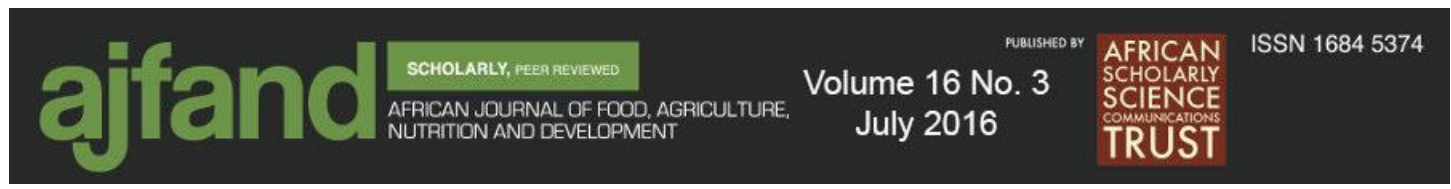

74. Southern LL and AJ Clawson Effects of Aflatoxins on Finishing Swine. J. Anim. Sci. 1979; 49: 1006-1011.

75. Panangala VS, Giambrone JJ, Diener UL, Davis ND, Hoerr FJ, Mitra A, Schultz RD and GR Wilt Effects of Aflatoxin on the Growth Performance and Immune Responses of Weanling Swine. Am. J. Vet. Res. 1986; 47: 2062.

76. Lindemann MD, Blodgett DJ, Kornegay ET and GG Schurig Potential Ameliorators of Aflatoxicosis in Weanling/Growing Swine. J. Anim. Sci. 1993; 71: $171-178$.

77. Schell TC, Lindemann MD, Kornegay ET, Blodgett DJ and JA Doerr Effectiveness of Different Types of Clay for Reducing the Detrimental Effects of Aflatoxin-Contaminated Diets on Performance and Serum Profiles of Weanling Pigs. J. Anim. Sci. 1993; 71: 1226-1231.

78. Schell TC, Lindemann MD, Kornegay ET and DJ Blodgett Effects of Feeding Aflatoxin-Contaminated Diets With and Without Clay to Weanling and Growing Pigs on Performance, Liver Function, and Mineral Metabolism. J. Anim. Sci. 1993; 71: 1209-1218.

79. Harvey RB, Kubena LF, Elissalde MH, Corrier DE and TD Phillips Comparison of Two Hydrated Sodium Calcium Aluminosilicate Compounds to Experimentally Protect Growing Barrows from Aflatoxicosis. J. Vet. Diagnostic Investig. 1994; 6: 88-92.

80. Harvey RB, Kubena LF and MH Elissalde Effects of Aflatoxin on Tocopherol and Retinol Concentrations in Growing Barrows. Agri-Practice 1995.

81. Harvey RB, Edrington TS, Kubena LF, Elissalde MH and GE Rottinghaus Influence of Aflatoxin and Fumonisin B1-containing Culture Material on Growing Barrows. Am. J. Vet. Res. 1995; 56: 1668-1672. 